\title{
PENDEKATAN PENINGKATAN PRODUKSI LELE PADA KELOMPOK PEMBUDIDAYA IKAN SURYA PERKASA DESA GENDONGKULON, BABAT, LAMONGAN MELALUI IMPLEMENTASI PROBIOTIK DAN TEKNOLOGI PASCAPANEN
}

\author{
APPROACH TO INCREASING LELE PRODUCTION IN SOLAR FISHING CULTURE \\ GROUPS PERKASA DESA GENDONGKULON, BABAT, LAMONGAN THROUGH PROBIOTIC \\ IMPLEMENTATION AND PASCAPANEN TECHNOLOGY
}

\author{
Heru Pramono \\ Fakultas Perikanan dan Kelautan \\ Dwi Yuli Pujiastuti \\ Fakultas Perikanan dan Kelautan \\ Sofi Maulana \\ Fakultas Perikanan dan Kelautan \\ Abdul Azis \\ Fakultas Perikanan dan Kelautan
}

\begin{abstract}
ABSTRAK
Produksi pangan melalui industri budidaya merupakan salah satu opsi menjanjikan karena mampu mendukung kebutuhan gizi masyarakat, terutama dari segi kecukupan protein hewani. Salah satu produk budidaya yang menjanjikan adalah budidaya ikan lele (Clarias batracus) karena ikan lele dikenal mampu tumbuh dalam kondisi air yang relatif kurang baik, memiliki waktu pertumbuhan relatif pendek (2-3 bulan). Meskipun demikian munculnya penyakit yang menyebabkan kematian massal serta penghasilan pembudidaya yang menurun menjadi permasalahan utama belakangan ini. Oleh karena itu, tujuan pengabdian kepada masyarakat ini adalah upaya mengatasi kematian massal guna meningkatkan produksi lele serta diversifikasi olahan ikan pasca panen untuk meningkatkan penghasilan masyarakat. Pendekatan yang dilakukan meliputi isolasi dan karakteristik bakteri penyebab kematian massal, resistansi bakteri terhadap antibiotik, produksi probiotik indigenous, serta pelatihan pembuatan olahan lele. Hasil pengabdian menunjukkan bahwa terdapat bakteri yang tahan terhadap antibiotik hasil isolasi dari lele yang mengalami penyakit selama bulan Juli sampai Oktober. Selain itu juga telah dilakukan upaya produksi probiotik indigenous dari saluran pencernaan lele yang bertahan hidup dari kematian massal, dan pelatihan pengolahan snack berbahan ikan lele di lokasi. Respons yang baik ditunjukkan pada pelatihan pengolahan serta diharapkan ke depan kedua upaya ini mampu meningkatkan kemandirian ekonomi masyarakat.
\end{abstract}

Kata kunci: probiotik, bakteri resisten antibiotik, diversifikasi olahan lele

\section{ABSTRACT}

Food production through the cultivation industry is one of the promising options because it is able to support the nutritional needs of the community, especially in terms of the adequacy of animal protein. One promising aquaculture product is catfish culture (Clarias batracus) because catfish are known to be able to grow in relatively unfavorable water conditions, have relatively short growth times (2-3 months). Nonetheless, the emergence of diseases that cause mass death and decreased cultivator income have become the main problems lately. Therefore, the purpose of community service is to overcome mass death in order to increase catfish production and diversify post-harvest fish processing to increase community income. The approach includes isolation and characterization of bacteria that cause mass death, bacterial resistance to antibiotics, indigenous probiotic production, and training in making catfish. The results of the dedication showed that there were bacteria that were resistant to antibiotics from isolation from catfish that experienced disease during July to October. In addition, efforts have been made to produce indigenous probiotics from the catfish digestive tract that 
survive mass death, and training in processing catfish snacks on site. A good response is shown in processing training and it is hoped that in the future these two efforts will be able to increase the economic independence of the community.

Keywords: probiotics, antibiotic resistant bacteria, catfish processed diversification

\section{PENDAHULUAN}

Seiring dengan pertambahan jumlah penduduk, kebutuhan akan pangan yang sehat semakin meningkat. Produksi pangan melalui industri budidaya merupakan salah satu opsi menjanjikan karena mampu mendukung kebutuhan gizi masyarakat, terutama dari segi kecukupan protein hewani. Salah satu produk budidaya yang menjanjikan adalah budidaya ikan lele (Clarias batracus) karena ikan lele dikenal mampu tumbuh dalam kondisi air yang relatif kurang baik, memiliki waktu pertumbuhan relatif pendek ( $2-3$ bulan) serta relatif tahan terhadap penyakit. Respons masyarakat terhadap ikan lele juga cukup baik karena ikan tersebut dapat ditemukan dalam jumlah mencukupi dan segar. Oleh karena itu, upaya dalam mempertahankan produktivitas budidaya ikan lele merupakan salah satu prioritas dalam mendukung ketahanan pangan nasional.

Salah satu wilayah produsen lele potensial di Jawa Timur adalah Kabupaten Lamongan. Total produksi lele Kabupaten Lamongan cukup tinggi dan hal tersebut dikarenakan pengembangan teknologi budidaya yang semakin meningkat. Budidaya lahan sempit dengan menggunakan sistem semi tertutup (terpal bulat) merupakan teknologi yang mulai dikembangkan di Lamongan. Kelompok pembudidaya ikan (Pokdakan) Surya Perkasa merupakan pembudidaya ikan yang berkedudukan di Lamongan dengan core bisnis berupa budidaya ikan lele dengan sistem semi intensif dengan menggunakan kolam bulat.

Pokdakan Surya Perkasa terletak di Desa Kedongkulon Kecamatan Babat, Lamongan dan bergerak di aneka usaha perikanan. Artinya usaha yang dilaksanakan oleh Pokdakan Surya Perkasa meliputi upaya pembenihan, pembesaran, pemasaran, dan pengolahan. Terdapat 20 orang anggota kelompok yang tergabung dalam Pokdakan Surya Perkasa. Meskipun demikian, hanya tiga orang anggota yang aktif melaksanakan usaha budidaya tersebut dikarenakan permasalahan yang belakangan ini muncul di usaha budidaya semi intensif, yaitu kematian benih massal dan pemasaran yang kurang menjanjikan kontinuitas.

Kematian benih lele yang sedang ditebar umumnya disebabkan oleh beberapa faktor, diantaranya adalah ikan mengalami stres sehingga rentan terhadap serangan hama dan penyakit. Hama dan penyakit berbahaya yang dapat menyebabkan kematian massal pada benih ikan yang ditebar salah satunya adalah bakteri dari jenis Aeromonas hydrophylla. Bakteri tersebut memiliki ketahanan yang tinggi terhadap berbagai lingkungan dan mampu tahan terhadap antibiotik. Penggunaan antibiotik secara tidak terukur diduga menjadi salah satu penyebab terjadinya penyebaran penyakit yang disebabkan oleh bakteri Aeromonas hydrophylla. Oleh karena itu, upaya untuk menghentikan penyebaran bakteri tersebut di usaha budidaya diharapkan mampu meningkatkan produktivitas perikanan Lamongan, terutama pada Pokdakan Surya Perkasa yang diharapkan sebagai percontohan dalam sistem pengelolaan kolam yang lebih efektif.

Aspek kedua yang perlu ditingkatkan untuk mengatasi permasalahan keaktifan pembudidaya adalah aspek pemasaran. Aspek pemasaran ikan lele sebenarnya tidak terlalu menjadi permasalahan, namun kontinuitas produksi merupakan kendala utama dalam pemenuhan kebutuhan bulanan masyarakat pembudidaya. Usaha untuk melakukan diversitas produksi dapat menjadi alternatif dalam memberikan penghasilan rutin bulanan bagi masyarakat pembudidaya ikan.

Upaya untuk mengatasi kematian massal yang disebabkan oleh bakteri Aeromonas hydrophilla serta diversifikasi produksi yang menjamin kontinuitas penghasilan bulanan pembudidaya dapat menjadi alternatif peningkatan produktivitas masyarakat pembudidaya ikan. Program pengabdian kepada masyarakat ini ditujukan untuk menyediakan alternatif solusi bagi Pokdakan Surya Perkasa sehingga ke depan diharapkan mampu memperluas dampak positif bagi kelompok pembudidaya lainnya.

\section{METODE PELAKSANAAN}

\section{Permasalahan dalam Bidang Produksi}

Secara rinci, pelaksanaan solusi yang ditawarkan dalam Pengabdian kepada Masyarakat ini adalah sebagai berikut. Untuk permasalahan kematian massal akan dilakukan program:

1. Penyuluhan manajemen kualitas air untuk mencegah penyebaran penyakit penyebab kematian massal ikan lele

Program akan diawali dengan penyuluhan manajemen kualitas air untuk mencegah penyebaran penyakit penyebab kematian massal ikan lele. Pada program ini akan diundang pemateri yang merupakan ahli budidaya 
dan penyakit ikan dari Fakultas Perikanan dan Kelautan Universitas Airlangga. Penyuluhan akan difokuskan pada:

a. Cara budidaya ikan lele yang baik

b. Manajemen kualitas air bagi budidaya ikan lele sistem semi intensif

c. Deteksi dini penyakit penyebab Aeromonas hydrophylla

d. Alternatif penanganan kualitas air yang tidak sesuai dengan pendekatan keilmuan kekinian

2. Deteksi resistensi antibiotika bakteri Aeromonas hydrophylla yang terdapat di kolam budidaya lele Pokdakan Surya Perkasa

Program deteksi resistensi antibiotika bakteri Aeromonas hydrophylla yang terdapat atau menyerang benih akan dilakukan oleh ahli mikrobiologi Fakultas Perikanan dan Kelautan Universitas Airlangga. Luaran dari solusi ini berupa pola resistansi antibiotika serta saran untuk tidak menggunakan antibiotika tertentu yang tidak efektif mengatasi permasalahan. Lebih lanjut akan dikembangkan sistem probiotik dalam implementasi mengatasi permasalahan bakteri resistan tersebut. Tahapan operasional program deteksi resistansi antibiotika bakteri ini terdiri atas:

a. Isolasi bakteri penyebab penyakit pada benih ikan lele di Pokdakan Surya Perkasa dengan menggunakan metode eksisi dan ditumbuhkan pada medium spesifik. Sebanyak satu gram sampel akan dihomogenisasi dengan larutan fisiologis dan diplate pada media spesifik Aeromonas dan di inkubasi pada suhu $30^{\circ} \mathrm{C}$ selama 24 jam. Kultur yang diperoleh akan dipurifikasi dengan metode gores dan disimpan pada medium TSA agar miring hingga dilakukan uji resistensi.

b. Identifikasi isolat dilakukan dengan menggunakan alat deteksi bakteri yang terdapat di laboratorium Mikrobiologi, Fakultas Perikanan dan Kelautan, Universitas Airlangga.

c. Uji resistensi dilakukan terhadap 7 antibiotika dari 5 kelas yang berbeda dengan metode mikrodilusi.

d. Hasil pola resistansi antibiotika ditentukan dengan mengacu pada standar CLSI.

\section{Permasalahan dalam Bidang Manajemen dan Pemasaran}

Untuk permasalahan kontinuitas penghasilan bulanan anggota kelompok, maka akan dilakukan:

1. Penyuluhan diversifikasi pengolahan ikan lele

Tahapan implementasi penyuluhan diversifikasi produk olahan ikan lele akan dilakukan pada Pokdakan Surya
Perkasa, termasuk bagi ibu rumah tangga anggota Pokdakan. Tahapan program adalah sebagai berikut:

a. Pengurusan izin lokasi dan penentuan hari penyuluhan

b. Penyampaian metode diversifikasi produk olahan lele:

1. Definisi Diversifikasi olahan lele

2. Desain pengemasan produk olahan

3. Metode pemasaran online melalui Facebook, Instagram, dan media massa

c. Evaluasi pemahaman terhadap materi yang telah disampaikan.

3. Start up bisnis diversifikasi pengolahan ikan lele

Start up bisnis diversifikasi pengolahan ikan lele akan diimplementasikan melalui:

a. Penyediaan sarana dan prasarana produksi, kerja sama dengan mitra. Mitra akan menyediakan lokasi produksi dan sebagian sarana, sedangkan tim pengabdian akan menyumbangkan peralatan produksi yang relevan.

b. Pengaturan lokasi produksi mengikuti prosedur sistem tata letak (layout) berdasarkan operasional produk yang akan dikembangkan.

c Penentuan jenis dan kapasitas produksi diversifikasi lele dan pembentukan sistem manajemen keuangan, pemasaran, dan pengembangan

d. Workshop pengolahan abon lele, nugget lele, sempol lele, dan amplang lele

e Workshop dan pemasaran produk olahan lele melalui media sosial

\section{HASIL DAN PEMBAHASAN}

\section{Survei Lokasi dan Penjaringan Aspirasi}

Tahap pertama yang dilaksanakan dalam rangkaian pengabdian kepada masyarakat Kelompok Pembudidaya Ikan (Pokdakan) Surya Perkasa adalah dengan mengadakan survey lokasi dan penjaringan aspirasi anggota. Berdasarkan kegiatan yang telah dilaksanakan, dapat diketahui bahwa Pokdakan Surya Perkasa mengalami kendala terutama pada keanggotaan. Pada awal pembentukan terdapat 10 anggota yang aktif untuk mengadakan kegiatan budidaya, namun saat ini yang tersisa adalah 3 (tiga) orang anggota yang aktif. Pada saat kunjungan survei dilaksanakan, selain 3 anggota yang aktif, lima anggota lain yang saat ini belum aktif lagi melaksanakan budidaya lele juga ikut hadir dan menyampaikan aspirasi terkait dengan budidaya lele di Pokdakan Surya Perkasa.

Hasil diskusi yang berupa Focus Group Discussion (FGD) di rumah ketua Pokdakan Surya Perkasa adalah beberapa hal 
terkait dengan kendala dan alternatif solusi yang diupayakan. Secara umum hasil diskusi tersebut adalah:

1. Kendala Penyakit ikan dan dapat menyebabkan kematian benih

2. Kendala pertumbuhan ikan lele yang lambat

3. Kendala pemasaran

4. Kendala penghasilan yang tidak konstan dari hasil budidaya lele

Kendala penyakit yang banyak dikeluhkan merupakan permasalahan utama. Hal ini dapat menyebabkan kerugian besar bagi pembudidaya lele karena menyebabkan kematian massal benih lele yang baru ditebar. Umumnya penyakit ditandai dengan munculnya bintik putih pada kulit lele dan berikutnya menjadi bintik merah dan perut kembung. Berdasarkan hasil studi literasi, dapat diketahui bahwa penyakit tersebut dimungkinkan karena infeksi bakteri patogen jenis Aeromonas hydrophilla yang umum menyerang ikan yang dipelihara dengan kondisi yang kurang mendukung.

Kendala pertumbuhan yang lambat juga menyebabkan kerugian pada pembudidaya karena dalam proses pemeliharaan masih sangat tergantung pada pakan buatan (pellet) dengan harga yang relatif mahal. Oleh karena itu, pembudidaya lele umumnya menggunakan probiotik yang dapat meningkatkan pertumbuhan ikan lele. Meskipun demikian, probiotik yang dibeli di pasaran, bahkan ada yang dibeli dari media online masih belum dapat menyelesaikan permasalahan. Ikan lele yang dipelihara dinilai tetap lambat tumbuh sehingga pembengkakan biaya pemeliharaan akibat pakan yang terus diberikan menjadi permasalahan yang penting untuk diselesaikan.

Tidak kalah penting, permasalahan pemasaran juga merupakan kendala yang dihadapi oleh para pembudidaya ikan. Hal ini dikarenakan ikan dijual dalam kondisi segar kepada tengkulak dan mayoritas tengkulak telah memiliki pasar yang tersendiri. Secara tidak langsung, harga pasar ditentukan oleh para tengkulak itu sendiri. Berdasarkan hasil FGD diketahui bahwa harga lele di pasaran bisa mencapai 20.000 per $\mathrm{kg}$ namun harga di pembudidaya dipatok hanya sekitar 14.000 per $\mathrm{kg}$ atau bahkan dapat lebih rendah dari itu.

Aspek kontinyuitas penghasilan menyebabkan mayoritas pembudaya lele berhenti dari kegiatan budidaya. Hasil FGD dari pembudidaya yang berhenti melakukan upaya budidaya ikan lele menunjukkan bahwa para pembudidaya harus bekerja lebih keras karena penghasilan yang diperoleh dari budidaya tidak mencukupi. Akibatnya, para pembudidaya harus bekerja di dua atau tiga tempat yang berbeda. Aspek ini akan ditelaah lebih lanjut dan menjadi program lanjutan berupa pengolahan produk lele untuk mendapatkan penghasilan yang jauh lebih menjanjikan dan kontinyu jika dibandingkan dengan hanya budidaya saja.

\section{Pengambilan Sampel Ikan Lele untuk Identifikasi Bakteri Penyebab Penyakit}

Untuk menyelesaikan permasalahan pertama dan kedua, yaitu penyakit dan pertumbuhan ikan lele yang dinilai kurang baik maka pada tahapan berikutnya dilaksanakan proses sampling ikan lele, baik yang sehat maupun yang sedang sakit. Kegiatan ini dibantu oleh tiga orang mahasiswa semester 7 yang akan menggunakan data tersebut sekaligus untuk sampel penelitian skripsi. Sehingga, hasil pengabdian kepada masyarakat ini selain berusaha mengatasi masalah yang muncul di masyarakat juga sekaligus wahana edukasi riil bagi mahasiswa UNAIR. Gambar ikan dari hasil survei yang mengalami penyakit ditunjukkan oleh Gambar 4.1 ini.

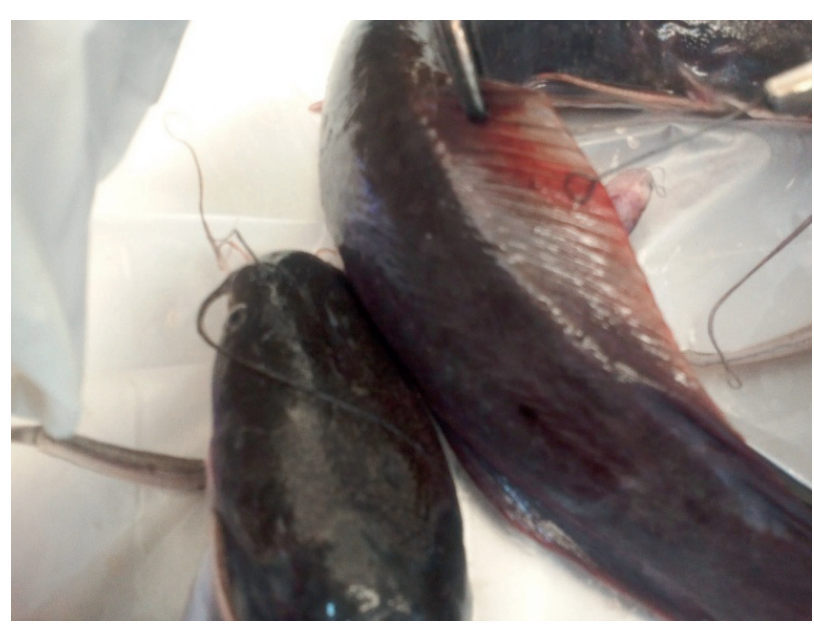

Gambar 4.1. Ikan lele yang mengalami serangan penyakit, sirip berwarna merah dan kulit pucat

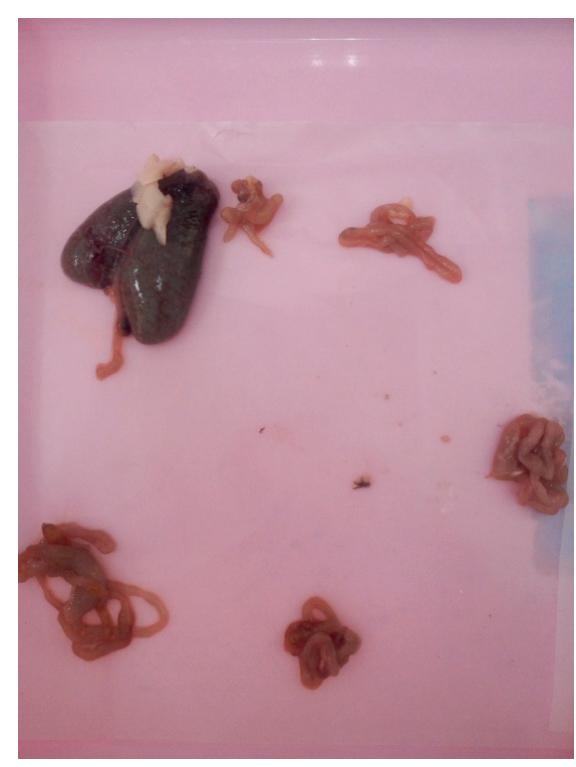

Gambar 4.2. Organ usus lele yang diambil untuk mendeteksi penyakitsekaligus mencarialternatif probiotikindegenous 
Sampling dilakukan dengan menggunakan peralatan steril dan dilakukan langsung di lapang. Sampel berupa ikan lele yang segar maupun ikan sakit diambil bagian sirip, usus, insang maupun dagingnya. Sampel tersebut disimpan dalam wadah plastik yang telah disterilkan dan disimpan dalam kotak dingin berinsulasi untuk menjaga kondisi riil lapang sebelum dilakukan analisis mikrobiologis di laboratorium. Organ yang diambil untuk sampel bakteri ditunjukkan oleh Gambar 4.2.

Uji laboratorium telah dilakukan di Laboratorium Mikrobiologi Fakultas Perikanan dan Kelautan, UNAIR. Hasil isolasi bakteri menunjukkan adanya 26 jenis bakteri yang diperoleh dari sampel. Sampel bakteri tersebut kemudian di purifikasi untuk mendapatkan galur murni isolat bakteri dan disimpan dalam dua medium untuk uji lanjutan, yaitu NA miring dan Gliserol steril. Untuk isolat yang disimpan pada NA miring disimpan pada refrigerator, sedangkan isolat yang disimpan pada gliserol steril disimpan pada freezer dengan suhu $-10^{\circ} \mathrm{C}$ sebelum dilakukan uji lebih lanjut.

Perkembangan terkini adalah telah dilakukan uji sensitivitas terhadap antibiotik pada 4 (empat) isolat pertama yang disinyalir merupakan penyebab penyakit pada lele. Hasilnya menunjukkan bahwa terdapat isolat bakteri yang tahan terhadap antibiotik tetrasiklin. Menurut kajian referensi, dapat diketahui bahwa penggunaan antibiotika pada sistem budidaya ikan dalam jangka waktu yang lama telah menyebabkan bakteri mengalami mutasi dan menjadi resisten/tahan terhadap antibiotika tersebut. Hal ini menyebabkan bakteri yang menyebabkan penyakit ikan saat ini tidak mudah untuk diobati dengan menggunakan antibiotik. Alternatif alami untuk mengatasi penyakit ini perlu dikembangkan untuk menjadi pengabdian kepada masyarakat yang berikutnya.

\section{Penyuluhan Cara Budidaya Ikan yang Baik}

Penyuluhan cara budidaya ikan yang baik kemudian menjadi rangkaian berikutnya dalam pengabdian kepada masyarakat ini. Hal ini dikarenakan berdasarkan survey langsung pada lokasi budidaya ikan lele yang telah dilakukan dirasa masih kurang mengelola air yang digunakan untuk budidaya ikan dengan baik. Air merupakan lingkungan yang sangat menentukan hasil budidaya ikan pada suatu lokasi. Apabila air yang digunakan terlalu banyak mengandung bahan organik, maka akan muncul banyak bakteri penyebab penyakit pada air tersebut yang pada akhirnya akan menyebabkan penyakit pada ikan. Sebaliknya, apabila air dapat dikendalikan dengan baik, maka penyakit tidak muncul pada ikan yang dibudidaya.
Hasil penyuluhan ini diharapkan ke depan pembudidaya ikan akan menjaga kualitas air yang digunakan dengan baik, yaitu dilakukan penggantian air setiap satu minggu sekali. Selama ini, para pembudidaya tidak mengganti air hingga air menjadi bau amoniak atau bau busuk. Alasan yang digunakan oleh para pembudidaya ikan adalah karena kalau tidak bau maka tidak akan menyebabkan penyakit. Untuk mencegah air menjadi bau, para pembudidaya juga menggunakan probiotik yang dibeli dari pasaran. Fakta nya, penggunaan probiotik hanya menghambat pertumbuhan bakteri penyakit, tidak mematikan bakteri penyakit sehingga apabila air tidak diganti secara berkala, maka penyakit tetap akan muncul walaupun telah menggunakan probiotik.

\section{Penyuluhan Pengembangan Produk Olahan Berbasis Ikan Lele}

Berikutnya, untuk menjaga stabilitas penghasilan para pembudidaya ikan lele, telah dilakukan penyuluhan pengolahan ikan lele menjadi added value products, yang artinya menjadi produk jadi yang memiliki nilai lebih tinggi. Proses penyuluhan dimulai dari pemberian sosialisasi mengenai jenis dan produk olahan ikan, metode produksi, dan metode pemasaran yang paling baik. Setelah itu, pada tahapan eksekusi dilanjutkan dengan pemberian keterampilan berupa workshop pembuatan produk olahan.

Pada tahap pertama, dilakukan penyuluhan di dalam ruangan bagi ibu-ibu dan anak perempuan kelompok pembudidaya ikan Surya Perkasa. Penyuluhan dihadiri cukup banyak peserta, namun para peserta dinilai masih belum memperoleh manfaat yang maksimal karena baru memperoleh pengetahuan dasar. Proses pelaksanaan penyuluhan ditunjukkan oleh Gambar 4.4.

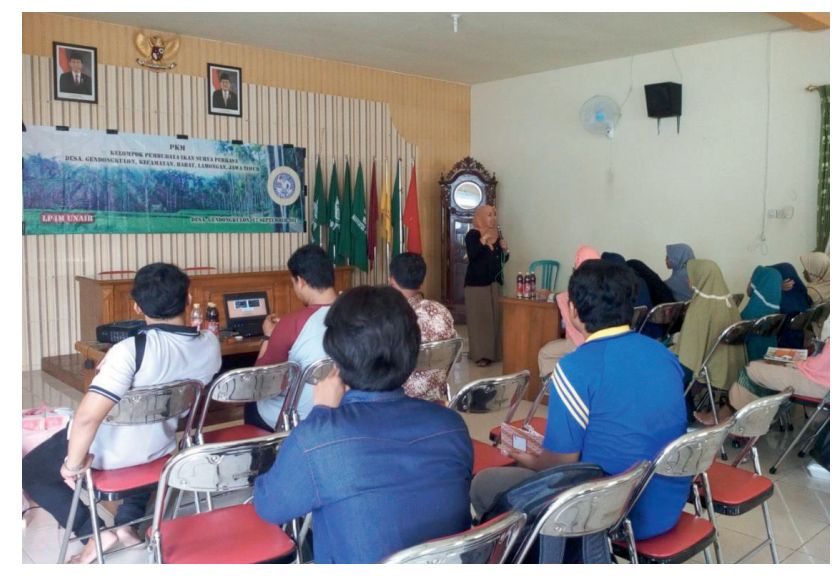

Gambar 4.4. Proses penyuluhan pengolahan ikan lele menjadi produk bernilai tambah 


\section{Workshop Pengolahan Ikan Lele}

Workshop pengolahan ikan lele telah dilaksanakan pada ibu-ibu dan remaja putri di Pokdakan Surya Perkasa. Workshop dilaksanakan dengan mengajari proses pengolahan ikan lele, yaitu:

\section{Fillet Ikan Lele}

Fillet ikan lele yang diproduksi adalah fillet ikan skinless yang artinya potongan daring ikan lele tanpa mengandung tulang dan kulit. Proses pengolahan dimulai dari pemberian petunjuk teknis oleh trainer dan dilanjutkan dengan demonstrasi cara memproduksi fillet ikan lele oleh trainer. Setelah dilakukan pemberian contoh sampai tiga kali, maka tahapan berikutnya adalah memberikan kesempatan pada peserta untuk melakukan filleting sendiri. Hasilnya, para ibu-ibu dan remaja Pokdakan Surya Perkasa bersemangat sehingga waktu yang harusnya hanya 1 jam pelatihan menjadi 2 jam praktek filleting oleh peserta.

\section{Stik Ikan Lele}

Produksi lanjutan dari fillet ikan yang dihasilkan adalah added value berupa stick lele. Stick lele tersebut diproduksi sesuai dengan urutan pada Gambar 5. Proses diawali dengan pembagian buku resep sederhana dan dilanjutkan dengan demonstrasi pengolahan. Pengolahan diawali dengan menghaluskan daging lele dengan menggunakan food processor beserta dengan bumbu yang ada, yaitu bawang merah dan bawang putih. Setelah itu, ditambahkan tepung terigu dan tepung tapioka untuk menjadi adonan. Penambahan telur sebanyak tiga butir dilakukan dengan menggunakan

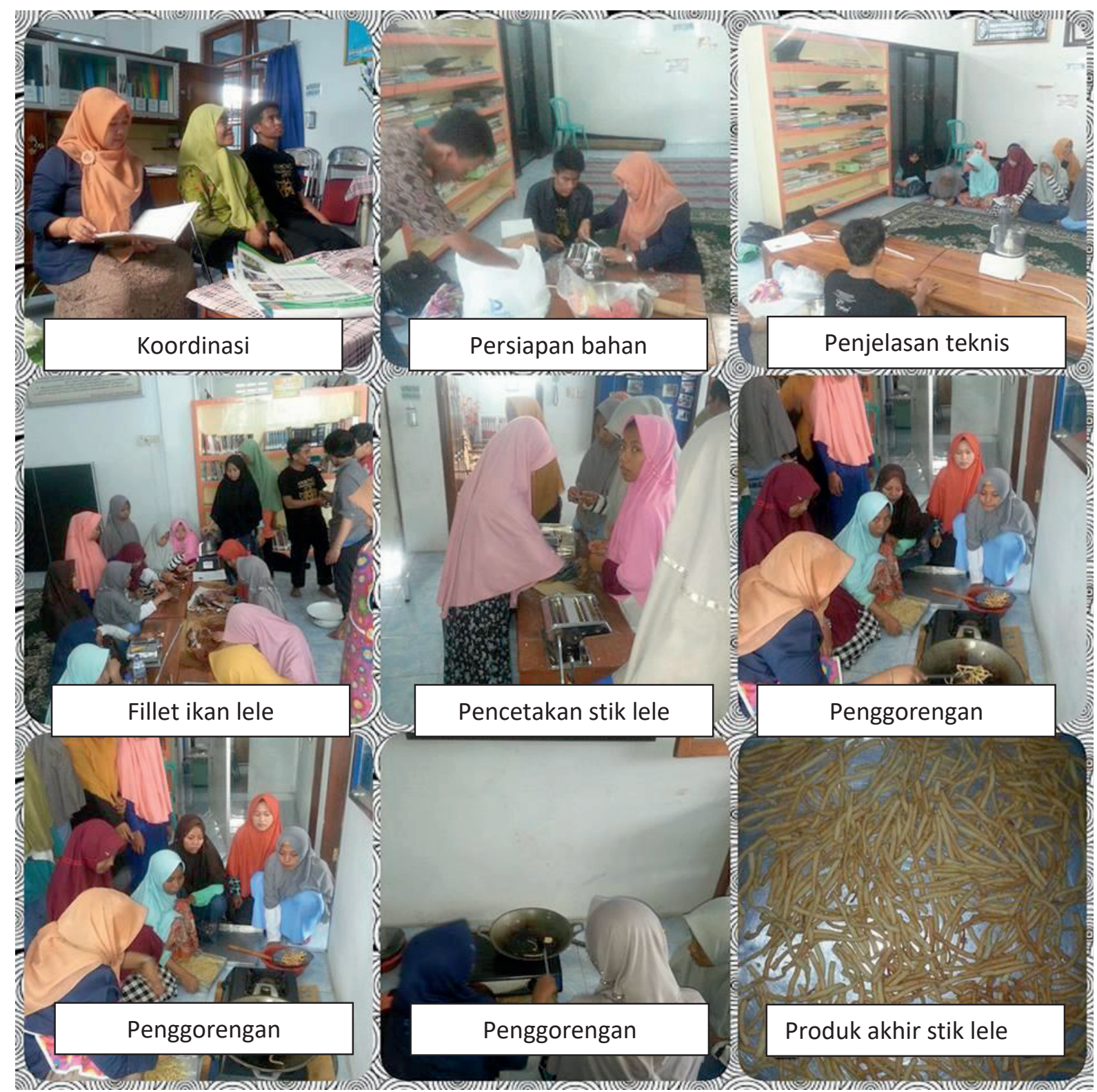

Gambar 4.5 Proses pengolahan stik lele 


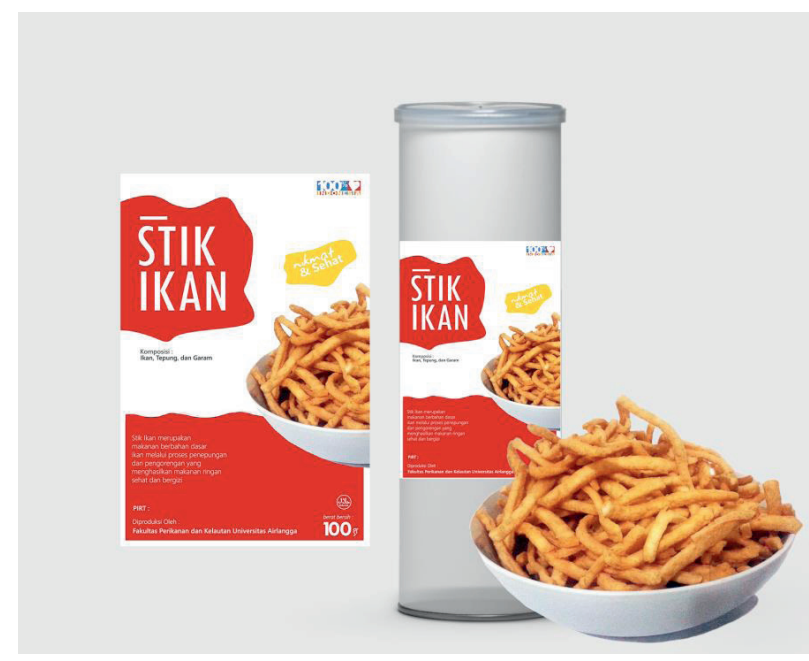

Gambar 4.6 Desain kemasan stik ikan lele

food processor dan dilanjutkan dengan menguleni secara manual dengan menggunakan tangan. Peserta bersemangat untuk melakukan praktek mandiri dan kemudian dilanjutkan dengan pencetakan adonan dengan menggunakan pemotong mie. Hasil pemotongan kemudian dicetak dan digoreng dan ditambah dengan bumbu beraneka rasa, seperti rasa balado, jagung manis, dan pedas. Hasil pengabdian ini diharapkan mampu meningkatkan konsumsi ikan di masyarakat yang baik bagi perkembangan tubuh.

\section{Pengemasan Stik Ikan Lele}

Tahapan berikutnya adalah pengemasan stik ikan lele. Kemasan yang digunakan merupakan plastik yang tahan panas dan pada bagian belakangnya adalah lembaran aluminium foil untuk menjaga kualitas dan higiene produk yang telah dihasilkan. Desain kemasan yang digunakan untuk pengabdian kepada masyarakat ini ditunjukkan oleh Gambar 4.6.

\section{Produksi Probiotik SUPER LELE (Probiotik SUrya PERkasa untuk Budidaya Lele)}

Hasil penelitian ini masih dalam tahap evaluasi laboratorium, sehingga produksi massal masih belum dapat dilaksanakan pada tahun berjalan. Meskipun demikian, dua orang mahasiswa yang terlibat dalam penelitian ini telah menggunakan bakteri yang diisolasi untuk tujuan penelitian skripsi sehingga pada tahun berikutnya diharapkan telah diketahui hasil uji laboratorium sebagai landasan aplikasi lapang. Uji laboratorium merupakan salah satu uji penting sebelum diaplikasikan di lapang untuk melakukan evaluasi bakteri pada: kemampuan untuk menghasilkan senyawa enzim yang baik bagi pertumbuhan bakteri, kemampuan bakteri untuk menghambat bakteri penyebab penyakit, serta kemampuan bakteri dalam tahan terhadap antibiotik. Masingmasing tahap diperlukan waktu sekitar dua minggu sampai satu bulan sehingga dalam prediksi tim pengemas pada bulan Februari 2018 akan dapat dihasilkan SUPER LELE bagi kelompok.

Saat ini tahapan yang telah dilaksanakan adalah mendapatkan isolat bakteri sebanyak 30 isolat yang telah diuji kemampuan untuk resistansi terhadap antibiotik. Dasar ini kemudian juga telah dilakukan untuk menentukan kemampuan berikutnya yaitu kemampuan anti bakteri dari isolat bakteri yang dimiliki.

\section{Hasil Pengabdian Kepada Masyarakat PkM Pokdakan Surya Perkasa}

Hasil pengabdian kepada masyarakat pada kelompok pembudidaya ikan Surya Perkasa telah cukup dirasakan, terutama pada produk pengolahan ikan lele. Hasil pelatihan telah diimplementasikan dan bahkan telah diupayakan untuk mengikuti pameran produk hasil perikanan pada wilayah setempat.

\section{KESIMPULAN \& SARAN}

\section{UCAPAN TERIMA KASIH}

\section{DAFTAR PUSTAKA}

